\title{
The Ecological Spirituality in the Light of Laudato sì
}

Ivan Platovnjak*

ivan.platovnjak@teof.uni-lj.si https://doi.org/10.31192/np.17.1.5

UDK / UDC: 502/504:272.732.2(044.6)

Izvorni znanstveni rad / Original scientific paper

Primljeno / Received: 18. prosinca 2018. / Dec 18, 2018

Prihvaćeno / Accepted: 12. siječnja 2019. / Jan 12, 2019

Christians confess their faith in God the Creator of heaven and earth. The question is whether they have a different relationship to creation than those who do not look on creation in the light of faith in God the Creator. The majority is unaware that the fullness of Christian spirituality is lacking if the fruit of it does not include a greater ecological awareness manifesting in concrete care for a common home. The Catholic Church has long delayed the publication of official documents that promote environmental concerns. This restraint was overcome by Pope Francis through his encyclical Laudato sì, in which he highlighted the problems of ecological insecurity and a certain indifference of many Christians in relation to the environment. The pope addressed the encyclical to the whole of humankind, because he wanted to call all people to unite in a repeated common search and realization of concrete care for our common home. In this paper the author wants to first present the pope's criticism and encouragement in regard to solving the ecological crisis. Then he will present a way of ecological spirituality, to which he is inviting all humanity, and especially Catholics. At the end he will present two spiritual means, offered by Ignatian Spirituality (contemplation, exsamen), that enable a new relationship toward creation, which ecological spirituality is encouraging.

Key words: ecological spirituality, Pope Francis, ecology, Laudato sì, Trinitarian God, creation, Ignatian spirituality, contemplation, exsamen.

\footnotetext{
* Ivan Platovnjak, PhD, Assist. Prof., University of Ljubljana, Faculty of Theology; Address: Poljanska cesta 4, SI-1000 Ljubljana, Slovenia.
} 


\section{Introduction***}

Christians repeatedly confess their faith in God Creator of heaven and earth, a God who revealed himself to them and is revealing himself to them through the history of redemption that is written in the books of Old and New Testament as well as in the "book" of creation. The question is whether they have a different relationship to creation than all other people who don't look on creation in the light of faith in God the Creator. ${ }^{1}$ It would be interesting to research in this direction. However, one would probably find out that in relating to creation there is no noticeable difference between Christians and non-Christians. Some studies in the United States show that Christians are less responsible than non-believers to the environment. ${ }^{2}$ The survey, which was carried out to explore the understanding of the spirituality of Slovenian Catholics, suggests that in terms of attitude to the environment they do not differ much from other people. The results of this survey show that very few of them understand their spirituality in relationship with creation. The majority is not aware that they don't live their relationship with God, and thus their Christian spirituality, fully if their relationship to creation is not integrated into it. That fullness is lacking if the fruit of their spirituality does not include a greater ecological awareness manifest in concrete care for a common home.

The Catholic Church has long delayed the publication of official documents that promote environmental concerns. Globokar states that the reasons for the restraint of ecclesiastical teaching are very different: »one of them is also probably the belief that environmental movements promote 'green ideology', encourage pantheism and a new paganism. $\aleph^{3}$

This restraint was overcome by Pope Francis, who highlighted the problem of ecological insecurity and a certain indifference of many Christians in relation to the environment. In his encyclical, Laudato sì he wrote:

»Obstructionist attitudes, even on the part of believers, can range from denial of the problem to indifference, nonchalant resignation or blind confidence in technical solutions. We require a new and universal solidarity«. ${ }^{4}$

\footnotetext{
**: The author acknowledges the bilateral project (Ethical Foundations of Sustainable Technologies from the Perspective of a Smart Local Community: Comparative Analysis between the Silicon Valley and Slovenia, BI-US/17-18-048) was financially supported by the Slovenian Research Agency.

${ }^{1}$ Cf. Piotr ROSZAK, Wiarygodność i tożsamość. Teologia wiary św. Tomasza z Akwinu $i$ wspótczesność [Credibility and Identity. Theology of Faith in Thomas Aquinas and contemporary thinking], WAM, Kraków 2013, 120.

${ }^{2}$ Cf. Roman GLOBOKAR, Krščanski antropocentrizem in izkoriščevalska drža človeka do naravnega okolja [Christian Anthropocentrism and Man's Exploitative Stance toward the Natural Environment], Bogoslovni vestnik, 78 (2018) 2, 349-364, 354.

${ }^{3}$ Ibid., 362.

${ }^{4}$ Pope Francis, Encyclical Letter Laudato sì, May 24 ${ }^{\text {th }}$ 2015, http://w2.vatican.va/content/ francesco/en/encyclicals/documents/papa-francesco_20150524_enciclica-laudato-si.html
} 
Pope Francis addressed the encyclical not only to the entire Catholic Church but also to the whole humankind, also because he wanted to call all people to unite in a repeated common search and realization of concrete care for our common home, as reflected in the full title of his Encyclical: Encyclical Letter Laudato si of the Holy Father Francis on Care for our Common Home. Beside that Pope Francis makes a call in the 14th Paragraph of this Encyclical:

»I urgently appeal, then, for a new dialogue about how we are shaping the future of our planet. We need a conversation which includes everyone, since the environmental challenge we are undergoing, and its human roots, concern and affect us all.$^{5}$

In our article we want at first to present the pope's criticism and encouragement in regard to solving the ecological crisis. Then we will present a way of ecological spirituality, to which he is inviting all humanity, and especially Catholics. At the end we will present two spiritual means, offered by Ignatian Spirituality, that enable the constitution of a new relationship toward creation, which ecological spirituality is encouraging.

\section{Pope's critique and incentive}

In his Encyclical Pope Francis first writes on St. Francis of Assisi who sang his Hymn Laudato sì and with it clearly stated that the Earth is our common home, a sister with which we share life and a good mother that accepts us in her embrace. ${ }^{6}$ But this very same Earth is in our time grieved by the irresponsible conduct of the humanity which is irresponsibly using and abusing the goods given to her by God, because it grew up in a conviction that it was the lord and master of the Earth, »entitled to plunder her at will«?

In the first Chapter of the Encyclical Pope Francis describes without embellishment those fundamental things that are destroying our Earth, our common home, and are causing deterioration in the quality of life: pollution, waste and the throwaway culture, warming of the climatic system, depletion of natural water resources, loss of biodiversity, disproportionate and unruly growth of cities, social exclusion of the poor, unequal access to energy and possible use of it and different services, increase of violence, social stratification and global inequality. ${ }^{8}$ At the end of the document the Pope reiterates his previous words with the goal of making the readers more aware of the reality he described:

(23.09.2018), 14.

5 Ibid.

${ }^{6}$ Cf. ibid., 1.

7 Ibid., 2.

${ }^{8}$ Cf. ibid., 17-52. 
»These situations have caused sister earth, along with all the abandoned of our world, to cry out, pleading that we take another course «. ${ }^{9}$

However, the Pope doesn't stop with the description of the signs of the ecological crisis. He shows, as well, its roots that are getting to the very perception of the world and of the activity of man, which is oftentimes deformed. The pope claims that the most problematic are: the globalization of the technocratic pattern, the modern anthropocentrism, practical relativism and biological innovations..$^{10}$ At the same time Pope Francis expresses gratitude to all who have encouraged ecological awareness among people before him and the sadness that so few concrete fruits of it are to be seen:

»The worldwide ecological movement has already made considerable progress and led to the establishment of numerous organizations committed to raising awareness of these challenges. Regrettably, many efforts to seek concrete solutions to the environmental crisis have proved ineffective, not only because of powerful opposition but also because of a more general lack of interest «. ${ }^{11}$

Pope Francis is aware that different theoretical and practical approaches developed in regards to ecological questions, which offer a variety of solutions extending from one extreme to the other. Thus, at one extreme, we see

»those who doggedly uphold the myth of progress and tell us that ecological problems will solve themselves simply with the application of new technology and without any need for ethical considerations or deep change«. ${ }^{12}$

At the other extreme are those

"who view men and women and all their interventions as no more than a threat, jeopardizing the global ecosystem, and consequently the presence of human beings on the planet should be reduced and all forms of intervention prohibited «. ${ }^{13}$

The pope is deeply aware that there is no unique solution. That is why he encourages seeking more viable future scenarios that will have to be generated between these two extremes, since »This makes a variety of proposals possible, all capable of entering into dialogue with a view to developing comprehensive solutions « ${ }^{14} \mathrm{He}$ also admits that the Church herself »has no reason to offer a

\footnotetext{
${ }^{9}$ Ibid., 53.

${ }^{10}$ Cf. ibid., 106-136.

${ }^{11} \mathrm{Ibid}$., 14. For an example, see the so-called Christian Ecofeminism: »The main focus of the paper is the question of fundamental interconnectedness and interdependence, and the joint responsibility of man-nature relationship in the ethical-moral sense, which therefore represents the next step in the evolution of interpersonal relationships (interpersonal, and between man and nature) « [Nadja FURLAN ŠTANTE, Dialog in gostoljubje krščanskega ekofeminizma [Dialog and Hospitality of Christian Ecofeminism], Edinost in dialog, 70 (2015) 1-2, 87-97, 87.]

${ }^{12}$ Pope Francis, Encyclical Letter..., 60.

${ }^{13}$ Ibid.

${ }^{14}$ Ibid.
} 
definitive opinion; she knows that honest debate must be encouraged among experts, while respecting divergent views. $\aleph^{15}$

Because of the great complexity of the question of ecology, Pope Francis encourages all people of good will to an integral ecology that encompasses the individual and society alike. It is necessary to reflect on and cultivate an environmental, economic, social and cultural ecology, ${ }^{16}$ an ecology of daily life and a human ecology. ${ }^{17}$ The principle of a common good and of the justice between the generations needs to be evaluated anew, ${ }^{18}$ the dialogue on the environment in the international community as the dialogue for new national and local policies $^{19}$ and the dialogue and transparency in decision-making as the dialogue between politics and economy need to be strengthened altogether. ${ }^{20}$ Similarly to Pope Francis, these problems have also been considered by modern ethicists such as Peter Ulrich and Hans Küng. ${ }^{21}$

Although the pope dedicates his Encyclical to all people of good will and is open to dialogue with all, he wishes to show with it

»how faith convictions can offer Christians, and some other believers as well, ample motivation to care for nature and for the most vulnerable of their brothers and sisters. If the simple fact of being human moves people to care for the environment of which they are a part «,22

how much more should they be moved by their faith in God the Creator. By all means science and religion, with their distinctive approaches to understanding reality, are invited to enter into an intense dialogue that will be fruitful for both. ${ }^{23}$ At the same time we should resort to »the various cultural riches of different peoples, their art and poetry, their interior life and spirituality«. ${ }^{24}$ Because humanity has never so hurt and mistreated our common home as we have in the last two hundred years, we are called in a special way »to be instruments of God our Father «, ${ }^{25}$ so that our planet Earth might be what he dreamed of when he created it and might correspond with his plan for peace, beauty and fullness.

\footnotetext{
${ }^{15}$ Ibid., 61.

${ }^{16}$ Cf. ibid., 137-146.

${ }^{17}$ Cf. ibid., 147-155.

${ }^{18}$ Cf. ibid., 156-162.

${ }^{19}$ Cf. ibid., 164-181.

${ }^{20}$ Cf. ibid., 182-198.

${ }^{21}$ Cf. Mile MARINČIĆ, Integrativna gospodarska etika Petera Ulricha i novija etička strujanja [Integrative economic ethics of Peter Ulrich], Zagreb, Pergamena, 2016, 176-177.

22 Pope Francis, Encyclical Letter..., 64.

${ }^{23}$ Cf. ibid., 62.

${ }^{24}$ Ibid., 63.

${ }^{25}$ Ibid., 64.
} 


\section{Ecological spirituality}

Pope Francis offers no one-sided solutions which would be linked to any political or economic system in his Encyclical, but he leans on the social teaching of the Church and, in a special way, on former popes who also dealt with this question. He encourages an ecological spirituality which is founded on a theology of creation and Trinity that creation carries in itself like a seal of God. Christians in the light of the revelation believe that the world was created and is still being created by three Divine persons (the Father and the Son and the Holy Spirit), but each of them realizing his own work according to his own personal identity. ${ }^{26} »$ For Christians «, underlines Pope Francis,

»believing in one God who is trinitarian communion suggests that the Trinity has left its mark on all creation. [...] The Franciscan saint [Saint Bonaventure] teaches us that each creature bears in itself a specifically Trinitarian structure, so real that it could be readily contemplated if only the human gaze were not so partial, dark and fragile. In this way, he points out to us the challenge of trying to read reality in a Trinitarian key ${ }^{27}$

The Holy Trinity is Love in its highest meaning because they live in themselves a fullness of mutually self-giving love, a fullness of relationships. ${ }^{28}$ That is why the world that was created in the image of God, of the Holy Trinity, is also a web of relationships. Creatures, individually and together, tend to the Triune God and from Him every living being has an intrinsic tendency to be in relationship with others. ${ }^{29}$ In this way Christians can see in the universe any number of constant and secretly interwoven relationships. This leads them not only to marvel at the manifold connections existing among creatures, but also to discover a key to their own fulfillment. The Holy Father notes:

»The human person grows more, matures more and is sanctified more to the extent that he or she enters into relationships, going out from themselves to live in communion with God, with others and with all creatures. In this way, they make their own that trinitarian dynamism which God imprinted in them when they were created . $^{30}$

\footnotetext{
${ }^{26} \mathrm{Cf}$. Jason T. EBERL, The Ontological and Moral Significance of the Persons, Scientia et Fides, 5 (2017) 2, 217-236, doi: http://dx.doi.org/10.12775/SetF.2017.016 (30.10.2018); Wojciech ZYZAK, Teologiczne podstawy duchowości ekologicznej. Refleksja na kanwie encykliki papieża Franciszka Laudato sî' [Theological Foundations for Ecological Spirituality. Reflections based on Pope Francis' Encyclical Letter Laudato sí], in: Peter TIRPAK, Józef PARTYKA (ed.), Edukacja i duchowość ekologiczna [Education and ecological Spirituality], Ojców, Ojcowski Park Narodowy, 2017, 14.

${ }^{27}$ Pope Francis, Encyclical Letter..., 239.

${ }^{28}$ Cf. Piotr ROSZAK, Between Dialectics and Metaphor: Dynamics of Exegetical Practice of Thomas Aquinas, Angelicum, 3 (2013) 507-534.

${ }^{29}$ Cf. Erika PRIJATELJ, En Bog, Sveta Trojica in etična praksa [One God, Holy Trinity and Ethical Praxis], Bogoslovni vestnik, 78 (2018) 2, 443-450, 449.

${ }^{30}$ Pope Francis, Encyclical Letter..., 240.
} 
Everything is interconnected, and this invites Christians, and through them, all people to mature in an integral »spirituality of that global solidarity « ${ }^{31}$ which flows from the mystery of the Trinity. In this way Pope Francis doesn't seem to suggest a solution to the ecological crisis from the teaching and principles of Marxism, as many reproach him, but a different style of living which should be grounded on the positions and contents of Christian faith, and on dialogue with all religions, science, and with all people of good will, as well. ${ }^{32}$ He gives the example of St. Francis of Assisi, who not only warns of the attitude towards the Trinitarian God but also includes other religions in this dialogue, considering that it is necessary to give divine favor before the human being, in order to change the consciousness of certain people. ${ }^{33}$

Pope Francis explains his great desire very clearly:

»Here, I would like to offer Christians a few suggestions for an ecological spirituality grounded in the convictions of our faith, since the teachings of the Gospel have direct consequences for our way of thinking, feeling and living. More than in ideas or concepts as such, I am interested in how such a spirituality can motivate us to a more passionate concern for the protection of our world. A commitment this lofty cannot be sustained by doctrine alone, without a spirituality capable of inspiring us, without an 'interior impulse which encourages, motivates, nourishes and gives meaning to our individual and communal activity'. Admittedly, Christians have not always appropriated and developed the spiritual treasures bestowed by God upon the Church, where the life of the spirit is not dissociated from the body or from nature or from worldly realities, but lived in and with them, in communion with all that surrounds us«. ${ }^{34}$

The non-awareness of many Christians of how they cannot fully live their spirituality without its ecological dimension, is repeatedly mentioned as he says:

»that some committed and prayerful Christians, with the excuse of realism and pragmatism, tend to ridicule expressions of concern for the environment. Others are passive; they choose not to change their habits and thus become inconsistent $\ll^{35}$

That is why he accentuates that »the ecological crisis is also a summons to profound interior conversion $«{ }^{36}$ Ecological conversion makes it possible for Christians to make visible the effect of their encounter with Jesus and with

\footnotetext{
${ }^{31}$ Ibid.

${ }^{32}$ Cf. Erika PRIJATELJ, Healthy cultures: new challenges for interreligious dialogue, Synthesis philosophica, 32 (2017) 1, 109-120, doi: https://doi.org/10.21464/sp32108 (04.11.2018).

${ }^{33}$ Cf. Berislav ČOVIĆ, Mile MARINČIĆ, Social Responsibility for Healthy Society in the Context of Küng's Weltethos Project, Filozofska istraživanja, 36 (2015) 3, 473-491, 488, doi: https:// doi.org/10.21464/fi36305 (28.10.2018).

${ }^{34}$ Pope Francis, Encyclical Letter..., 216.

${ }^{35}$ Ibid., 217.

${ }^{36}$ Ibid.
} 
the world around them. It also helps them to gain a deeper sense of what it means to live their vocation of protectors of God's handiwork which by itself »is essential to a life of virtue; it is not an optional or a secondary aspect of our Christian experience ${ }^{37}$

Ecological conversion demands of each individual and of all humanity a recognition of our errors, sins, faults and failures, that leads to heartfelt repentance and a desire to change our attitudes, dispositions, or orientations, which are contrary to modern anthropocentrism. ${ }^{38}$ This ecological conversion must be collective. It demands durable changes in the attitudes towards creation and the way of living and activity. These attitudes are fostered by ecological spirituality, which is also realized through them.

1) The attitude of gratitude and gratuitousness. This attitude is founded on a recognition that »the world is God's loving gift, and that we are called quietly to imitate his generosity in self-sacrifice and good works even when no one sees it or recognizes it (Mt 6:3-4) «. ${ }^{39}$ One expression of this attitude is when we stop and give thanks to God before and after meals. The pope suggests to all believers »to return to this beautiful and meaningful custom $\ll^{40}$ That moment of blessing, however brief, reminds us of our dependence on God for life. It strengthens our sense of gratitude for the gifts of creation; it acknowledges those who, by their labours, provide us with these goods; and, for a Christian, it reaffirms the solidarity with those in greatest need.

Jesus Christ teaches and reveals with his life and activity that all people have God as their common Father and that in him all are brothers and sisters. »Fraternal love can only be gratuitous; it can never be a means of repaying others for what they have done or will do for us. That is why it is possible to love our enemies ${ }^{41}{ }^{11}$ This same gratuitousness inspires man to love and accept nature in all of its dimensions although it often doesn't act according to his will and enables him to live a universal brotherhood/sisterhood in gratitude and joy. ${ }^{42}$

2) The attitude of mutual life and respect towards the environment, of love and solidarity. In caring for their common home and the common good, everyone can collaborate as an instrument of God, each one with the riches of their own culture, with their own initiatives and capacities. ${ }^{43}$ We need to walk on the way of a cultural transformation ${ }^{44}$ which will be able to resist the throwaway

\footnotetext{
${ }^{37}$ Ibid.

${ }^{38}$ Cf. ibid., 115-136; Cf. Eugene R. SCHLESINGER, A Trinitarian Basis for a $»$ Theological Ecology « in Light of Laudato Si', Theological Studies, 79 (2018) 2, 339-355, 343-346, 351-335.

${ }^{39}$ Pope Francis, Encyclical Letter..., 200.

${ }^{40}$ Ibid., 227

${ }^{41}$ Ibid., 228.

${ }^{42}$ Cf. ibid., 228.

${ }^{43}$ Cf. ibid., 14, 63.

${ }^{44}$ Cf. ibid., 114.
} 
culture, ${ }^{45}$ of consumerism, ${ }^{46}$ of relativism and death ${ }^{47}$ and begin developing a culture of mutual life and respect towards the environment; a culture of love and solidarity. ${ }^{48}$ Love, interwoven with small gestures of mutual attention and care, does not concern only the relationships between individuals. ${ }^{49}$ Society can become more human if love becomes more understood as a gratuitous gift of God, and set on as a lasting and highest rule of life and activity. We all need to feel that we need others, that we are responsible for others and for the world, that it's worth it to be good and honest, since a careless superficiality brings us damage (228-229). ${ }^{50}$ It is also necessary to have a loving awareness that people are not disconnected from the rest of creatures, but joined in a splendid universal communion. Almost a hundred years ago, philosopher, theologian and humanitarian worker Albert Schweitzer also wrote of this inner connection with all living beings, and created the ethics of reverence for life, which in the modern world can also be the basis for a responsible attitude to all living beings. ${ }^{51}$

As Christians, they should not look at the world from without but from within, conscious of the bonds with which the Father has linked them to all beings. ${ }^{52}$ When someone feels that God is calling them to intervene with others in these social dynamics, »they should realize that this too is part of their spirituality, which is an exercise of charity «. ${ }^{53} \mathrm{In}$ this and through this they are matured and sanctified. In this way,

»the world, and the quality of life of the poorest, are cared for, with a sense of solidarity which is at the same time aware that we live in a common home which God has entrusted to us. These community actions, when they express self-giving love, can also become intense spiritual experiences «. ${ }^{54}$

3) The attitude of awareness of a common home and of commitment for the common good. The awareness of a common home is what should always direct the life and activity of all mankind. Every human is, by their dignity as a creation of God, invited and capable of collaborating by creating a common home. ${ }^{55}$ Pope Francis has, for that reason, dedicated the entire Encyclical Laudato sì to the whole of mankind so that in every human an awareness of

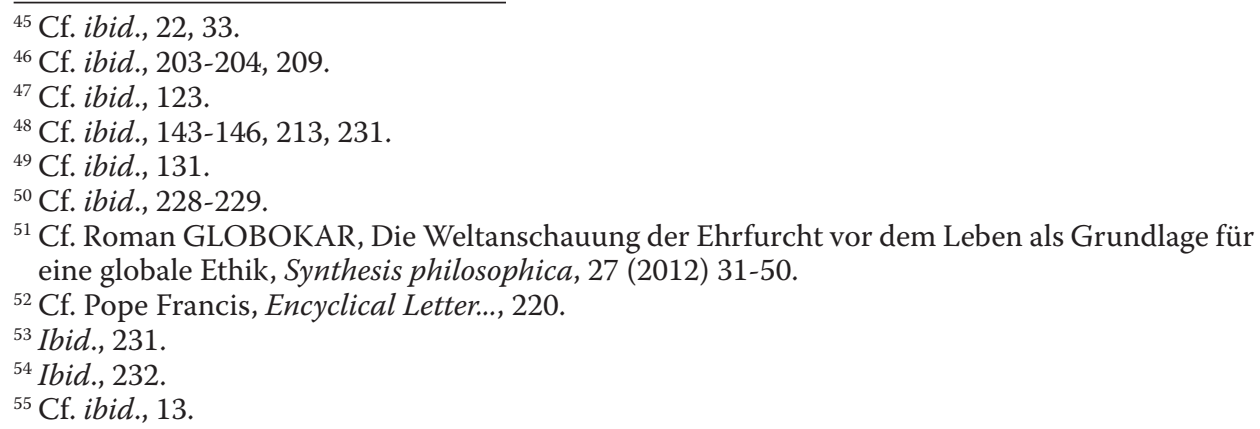


responsibility could be awakened for the care of a common home on all areas of activity. It is equally urgent to develop an awareness of the importance of commitment to a common good, which is the whole of those living conditions of social life, that make it possible for individuals and groups to achieve their greatest degree of fulfillment.

Underlying the principle of the common good is respect for the human person as such, a person endowed with basic and inalienable rights ordered to his or her integral development. Outstanding among those groups is the family as the basic cell of society. The common good calls for welfare and social security, especially social peace. Society as a whole, and the state in particular, »are obliged to defend and promote the common good $«{ }^{56}$ It is always necessary to keep before our eyes the common good for us and for all others, »for today and for tomorrow $\ll .57$

4) The attitude of moderation, joy and peace. Moderation, when lived freely and consciously, is liberating, brings joy, and leads to more life. Moderate people are those who do not let themselves be persuaded by the rapid pace of today's life-style and relentless striving to possess ever more. By their experience they know that it is possible to have few needs and still live a rich life, particularly when they cultivate other sources of pleasure and find satisfaction »in fraternal encounters, in service, in developing their gifts, in music and art, in contact with nature, and in prayer $«{ }^{58}$ Happy people are those who know how to resist the intoxication of advertisements and the culture of consumerism, remaining open to the many different possibilities which life can offer. It is not easy to mature into this kind of healthy humanity and happy moderation when someone considers himself or herself autonomous, when they exclude God from their lives or replace him with their own ego, and they believe that their subjective judgment can define what is good and what is evil. ${ }^{59}$

5) The attitude of sacramental life. The Sacraments that Christians celebrate »are a privileged way in which nature is taken up by God to become a means of mediating supernatural life $\ll .^{60}$ Religious ceremonies invite Christians to embrace the world on a different plane that is not merely material ${ }^{61}$ In Christianity and its experience,

"all the creatures of the material universe find their true meaning in the incarnate Word, for the Son of God has incorporated in his person part of the mate-

\footnotetext{
${ }^{56}$ Ibid., 157.

${ }^{57}$ Ibid., 135.

${ }^{58}$ Ibid., 223.

${ }^{59}$ Cf. ibid., 224.

${ }^{60}$ Ibid., 235.

${ }^{61}$ Cf. Bostjan LENART, Kakšno je miselno ozadje nasega pastoralnega dela [Conceptual Background of Our Pastoral Work], Bogoslovni vestnik, 70 (2010) 4, 605-614.
} 
rial world, planting in it a seed of definitive transformation. 'Christianity does not reject matter. Rather, bodylines is considered in all its value in the liturgical act, whereby the human body is disclosed in its inner nature as a temple of the Holy Spirit and is united with the Lord Jesus, who himself took a body for the world's salvation.' ${ }^{62}$

All creation reaches its greatest exaltation and culmination in the celebration of the sacrament of the Eucharist. The pope emphasizes:

»In the Eucharist it is the living center of the universe, the overflowing core of love and of inexhaustible life. Joined to the incarnate Son, present in the Eucharist, the whole cosmos gives thanks to God. Indeed, the Eucharist is itself an act of cosmic love ${ }^{63}$

6) The attitude of Sunday rest and celebration. Sunday is always in danger of becoming just like any other day of the week. However, it was given to Christians, and also to the rest of mankind, as a time of making a good of man's relationships with God, with himself, with others and with the world. Sunday is for them also »the day of the Resurrection, the 'first day' of the new creation, whose first fruits are the Lord's risen humanity, the pledge of the final transfiguration of all created reality «. ${ }^{64}$ Beside that it also proclaims »man's eternal rest in God «. ${ }^{65}$ Christian spirituality connects relaxation with festivity, since in this way it gets a deeper sense, helping man to become aware that he was given much gratuitously and that not everything depends on the work of his hands. ${ }^{66}$ Rest helps a man to discover the meaning of work, as »it protects human action from becoming empty activism; it also prevents the unfettered greed and sense of isolation which make us seek personal gain «. ${ }^{67}$ The commandment of weekly rest in the Old Testament wasn't meant only for the Jews but for all: »so that your ox and your donkey may have rest, and the son of your maidservant, and the stranger, may be refreshed « (Ex 23:12). In this way, Sunday rest, centered on

${ }^{62}$ Pope Francis, Encyclical Letter..., 235. Cf. Michał OLEKSOWICZ, In Search of the Person. Towards a Real Revolution, Scientia et Fides, 6 (2018) 1, 229-262, 230-257, doi: http://dx.doi. org/10.12775/SetF.2016.008 (30.10.2018).

${ }^{63}$ Pope Francis, Encyclical Letter..., 236.

${ }^{64}$ Ibid., 237.

${ }^{65}$ Ibid., 237.

${ }^{66}$ Cf. Grzegorz SZAMOCKI, Świętowanie niedzieli znakiem rozpoznawczym chrześcijan w perspektywie biblijnej teologii szabatu [The Celebration of Sunday as a Distinguishing Mark of Christians in the Perspective of Biblical Theology of the Sabbath], Studia Gdańskie, 38 (2016) 51-63, 53-58.

${ }^{67}$ Pope Francis, Encyclical Letter..., 237. Concerning the significance and consequences of greed in the Bible, see Samo SKRALOVNIK, Interpretacija poželenja v deseti Božji zapovedi [Interpretation of Desire in the Tenth Commandment], Bogoslovni vestnik, 73 (2013) 1, 59-76. »We could say that in the tenth commandment, "do not covet «, the essence of the Old testament economic ethos is summed up. The tenth commandment reveals the source of all the corrupted and sinful economic structures-the greed of the human heart. The planned effect of the tenth commandment is to reject the tendency for greed and personal interests to become the guiding principle of human behavior in this world « [ibid., 71]. 
the Eucharist, widens the view of a Christian since it sheds its light on the entire week, and encourages him to become aware not only of the value of those closest to him but also of the needs of nature and of the poor. ${ }^{68}$ The commandment of the Sabbath rest is also a sign of distributive divine justice: ${ }^{69}$ "God created us in his image, so that as custodians and administrators of creation we would allow every living creature to develop their life «. ${ }^{70}$

7) A contemplative style of existence. Ecological spirituality invites every man to "a prophetic and contemplative lifestyle, one capable of deep enjoyment free of the obsession with consumption $«{ }^{71}$ Of course this is true only if man takes up an ancient lesson, found in different religious traditions and also in the Bible. It is the conviction that »less is more «. ${ }^{72} \mathrm{~A}$ constant flood of new consumer goods can baffle the heart of man and prevent him from cherishing each thing and each moment. A serene presence to each reality, however small it may be, opens him to many more opportunities for a deeper awareness of how much was given to him and for his personal fulfillment. Of course, only the one who is reconciled to himself can mature in happy modesty. It is necessary to keep always before our eyes that inner peace for man »is closely related to care for ecology and for the common good $«{ }^{73}$ Because, if he lives it out authentically, this is reflected in his balanced lifestyle together with a capacity for wonder which takes him to a deeper level of existence and activity. Nature is filled with words of love. But how can man listen to them amid constant noise and nerve-wracking distraction, or the cult of self-evidence? An integral ecology demands that a Christian dedicates some time, also through meditation and contemplation, to recover a serene harmony with creation, reflecting on his lifestyle, his ideals, and contemplating the Creator who is present in every human and among all people as well as in what surrounds him, and »whose presence must not be contrived but found, uncovered $«{ }^{74}$ Such an attitude was fostered also in the history of Christian spirituality, as we know that

»Together with the awe-filled contemplation of creation which we find in Saint Francis of Assisi, the Christian spiritual tradition has also developed a rich and balanced understanding of the meaning of work, as, for example, in the life of Blessed Charles de Foucauld and his followers «. ${ }^{75}$

\footnotetext{
${ }^{68}$ Cf. Pope Francis, ibid., 237.

${ }^{69} \mathrm{Cf}$. Szamocki, Świętowanie niedzieli znakiem..., 59-60.

${ }^{70}$ Globokar, Krščanski antropocentrizem..., 360.

${ }^{71}$ Pope Francis, Encyclical Letter..., 222.

${ }^{72}$ Ibid.

${ }^{73}$ Ibid., 225.

${ }^{74} \mathrm{Ibid}$.

${ }^{75}$ Ibid., 125.
} 


\section{A contribution of Ignatian spirituality to ecological spirituality}

Pope Francis was formed in the Society of Jesus and as such feels that Ignatian spirituality is very close to him. However, in his Encyclical Laudato sì he never claims it directly. The central position has the spirituality of St. Francis, since the Encyclical carries its name after his well-known hymn Laudato sì. Of course, the Pope also mentions other saints and spiritualities, including Islam. Despite that we hold to the opinion that Ignatian spirituality also can contribute significantly to ecological conversion and to the development of an ecological spirituality, especially with its two prayer exercises which have, so to say, a central position in it. These are the Ignatian contemplation and the Ignatian Examen. They help a Christian, among other things, to develop a contemplative style of life as well as other attitudes which are important in actualizing ecological spirituality.

\subsection{Ignatian contemplation to attain love}

Ignatian contemplation is characterized by the use of the imagination's representational capacity the use of imagination representational capacity, and tasting and realizing things from the past and present which enable deeper contemplation. With the help of the imagination one can easily imagine or depict a thing, an event, persons or an encounter. Then he can focus on them integrally and creatively with all of his senses, and in and through them internally taste the presence of God and his goodness. ${ }^{76}$ It also allows him to be taught what all things and events say to him about God, as Jesus himself encourages all of us in the parable of the lilies of the field and the birds in the sky, etc. (Mt 6,26-30)

The exercise of the contemplation to attain love, ${ }^{77}$ which comes at the end of the 30-day Ignatian spiritual exercises, is preparing the one who is about to finish them for a contemplative life in his daily routine. Such a contemplation helps him to find God in all things and to become his co-speaker and collaborator. Or, put another way: it enables him to sense in all things - in all of creation included - the goodness and the self-giving love, to integrally respond to it, to surrender himself completely to it and to realize it in his own life.

Saint Ignatius knows that a man cannot directly find God in all things. Yet he is able to contemplate the goodness and the beauty of all created things and, in the light of faith, to see the presence of God who is creating all that and

\footnotetext{
${ }^{76}$ Cf. IGNACIJ LOYOLSKI, Duhovne vaje [Spiritual Exercises = Exx], Ljubljana, Župnijski urad Ljubljana - Dravlje, ${ }^{3} 1991$, No. 2.

${ }^{77}$ Cf. Exx, 230-237.
} 
giving it to him ${ }^{78}$ and prompting him in this way to become aware of the many gifts he has received through the universal brotherhood/sisterhood. The whole creation is, together with man and the mission that he gave him, very good, because it originated from God, who is love alone (1 Mz 1,31).

Saint Ignatius divided the Contemplation to Attain Love into four steps, so that everyone who enters into it, could fathom as deeply as possible the selfgiving love of God and respond to it in as integral a way as possible. The one making the contemplation is invited, on the ground of the awareness of what is essential for love and of the prayer for the grace of an intimate knowledge of the many blessings received, to first recall the blessings of creation and redemption, and the special favors received..$^{79}$ Then he observes how God dwells in him and gives him being, life, sensation, intelligence; and makes a temple of him. ${ }^{80}$ Then he is to consider how God works and labors for him in all creatures upon the face of the earth. ${ }^{81}$ At the end he considers all blessings and gifts as descending from God above as the rays of light descend from the sun, and as the waters flow from their fountains. ${ }^{82}$ As he sees and tastes all of this, he gradually realizes more and more how immensely blessed he is. Everything he is and has and that surrounds him, is a gift. This compels him intimately and stimulates, in his turn, wishes to become a gift and so, resembling the Giver, to collaborate with Him in His self-giving love for everyone and everything, caring for the common home and the common good. As a result of that he gives himself freely and consciously on disposal and desires to collaborate with Him in his daily life. ${ }^{83}$ Such an experience enables him to walk the path of ecological conversion and live, to the greatest degree possible in the attitudes of ecological spirituality.

To attain such a view on everything that exists and on life itself, in the midst of daily routine and the challenges of ecology, another prayer exercise can be of great help. That is the Examen.

\subsection{Examen - the possibility of making oneself aware of fundamental attitudes of ecological spirituality and their gradual actualization}

Examen is a very old form of making oneself aware of everything that is going on in one's life on a daily basis. The goal of the Examen is the growth of man's personal and passionate relationship with God and within him with himself, with others and with the whole of creation. Primarily it is intended

\footnotetext{
${ }^{78}$ Cf. Ian TOMLINSON, The Contemplation to Attain Love, The Way, 50 (2011) 4, 65-76, 74.

${ }^{79}$ Cf. Exx, 231-234.

${ }^{80}$ Cf. Exx, 235.

${ }^{81}$ Cf. Exx, 236.

${ }^{82}$ Cf. ibid.

${ }^{83}$ Cf. Exx, 234.
} 
to help discern or to open the eyes to the presence of God, that is of Love or Goodness and not to the moral judgment of what is good or bad. In other words: the Examen teaches us to see everything in the light of goodness and to permeate with love our sensitivity, imagination, mind and activity. That is why this exercise can be done by anyone, whether religious or not.

The Examen has five points or steps: a step of gratitude, a step of asking for light of the self-giving love, a step of reviewing the day that passed, a step of giving thanks and repentance, a step of a decision for self-giving love, for collaboration in the mutually self-giving love between the Father and the Son Jesus Christ in the power of the Holy Spirit. At first, a person is invited to calm down and recall the good things that happened during the day. Then they give thanks to God »for the favors received $«{ }^{84}$ For St. Ignatius it is essential that persons deepen their awareness of how greatly they are blessed with the goodness of God and how it is actively present in them and in everything that exists..$^{85}$ In this way they are becoming more and more capable of finding the goodness in all things, which is also fundamental for Ignatian spirituality. And where there is goodness, and love, there is also God (1 Jn 4).

For Ignatius it is everything that helps a person live and act, a gift of the attentive and self-giving love of God. Such recalling and thanksgiving are an antidote to dissatisfaction, which is so common in the culture of consumerism. ${ }^{86}$ When a person becomes aware of being immensely blessed, gratitude begins to awaken in them and with it a quiet contentment, peace and joy. ${ }^{87}$

In the second step of the Examen a person asks for the light of the Holy Spirit that they may know even more the self-giving love and its source. For St. Ignatius it is the blindness of man that makes it impossible for him to see how blessed he is and ingratitude for that is a fundamental sin. Because of that Ignatius invites them to ask for the grace to know their own blindness and to rid themselves of it. ${ }^{88}$

In the third step a person reviews the day from hour to hour in the received light of the presence of God and with His loving view of everything. ${ }^{89}$ Above all it is about making one aware of how God and His merciful and gratuitous love were present in one's life and activity (Louis 71-72). ${ }^{90}$ A person is invited to focus on the epiphany of goodness, the sacred, and to let them be blessed

\footnotetext{
${ }^{84} \operatorname{Exx}, 43$.

${ }^{85}$ Cf. Exx, 230-237; Donald St. LOUIS, The Ignatian Examen: A Method of Theological Reflection, Way Supplement, 55 (1986) 66-76, 68.

${ }^{86}$ Cf. Pope Francis, Encyclical Letter..., 184.

${ }^{87}$ Cf. Timothy M. GALLAGHER, The Examen Prayer. Ignatian Wisdom for Our Lives Today, New York, A Crossroad Book, 2006, 57-67.

${ }^{88}$ Cf. Exx, 43.

${ }^{89}$ Cf. ibid.

${ }^{90} \mathrm{Cf}$. St. Louis, The Ignatian Examen..., 71-72.
} 
anew with it. To the same it invites in some way a new philosophical movement called anatheism. ${ }^{91}$

The fourth step invites a person to regret their inability to be aware of their own blessings received and to ask for the grace of conversion. Only by the help of God and His gratuitous forgiveness, can a person become more and more able to respond to the gratuitous goodness of God and become also themselves a gratuitous and serving love for others and all creation, in the care of the common home and for the common good. ${ }^{92}$

Because of that they decide again in the fifth step for the self-giving love and solidarity so that the next day they will even more consciously collaborate with it. ${ }^{93}$ Such a daily conscious decision can help them to begin, in their feelings, imagination, thoughts, words and actions, developing the attitudes which are fundamental for ecological spirituality and to live them in all dimensions of their life and activity.

\section{Conclusion}

Pope Francis's Encyclical Laudato sì, is an encouragement not only for all people of good will, that they may gain a deeper awareness of the preciousness of the Earth as a common home and a responsible care for it, 'but also to all Catholics and all other Christians as well. His criticism of the relationship towards the common home is addressed also to all Christians. In the same way also the encouragements, especially toward a conscious implementation of ecological spirituality, the attitudes which makes it possible to live and practice them in one's daily life on a personal and communal level. An ecological spirituality is very important and it is impossible to respond integrally and responsibly to the needs of the common home or to the poor who are most affected by the ecological crisis without it. Christians above all are called to live an ecological spirituality in the light of Trinitarian self-giving love and solidarity. In this challenging endeavor St. Francis can be a forceful example for them. A change of life-style in the sense of the relationships of Divine persons in the Holy Trinity could, according to Pope Francis, bring a healthy pressure on those who have political, economic and social power to begin taking seriously the initiatives for a solution of the ecological crisis and to begin doing on their part everything possible so that the common home be preserved for

\footnotetext{
${ }^{91}$ Cf. Ivan PLATOVNJAK, Tone SVETELJ, Anatheism - an Incentive to Discover the Importance of Discipleship in Christianity, Bogoslovni vestnik, 78 (2018) 2, 375-386, 376-380.

${ }^{92}$ Cf. Tadej STEGU, Za svobodo osvobojeni: krščanska antropologija v katehezi [Set Free for Freedom: Christian Anthropology in Catechesis], Bogoslovni vestnik, 75 (2015) 3, 515-523.

${ }^{93}$ Cf. Exx, 43.
} 
future generations and that the poor who suffer most because of the ecological crisis are not forgotten.

By establishing such a new life-style two spiritual exercises, offered by Ignatian spirituality, can be a great help. These are Ignatian contemplation and the Examen. They can help a person be present in any reality, as small as it may be, and they can be aware of the realities that otherwise pass by unnoticed, realities that cannot open their senses, mind and heart for the essential in their lives and activity on a personal and communal level. The two spiritual exercises can, indeed, help them develop a respectful and responsible relationship towards the common home and, through ecological conversion, to grow in the attitudes that are fundamental for ecological spirituality as: the contemplative way of living, modesty and calmness, the capacity for being happy with little, gratitude and gratuitous self-giving love, solidarity, connectedness with everything, the universal brotherhood/sisterhood, rest and festivity, etc.

\section{Ivan Platovnjak* \\ Ekološka duhovnost u svjetlu enciklike »Laudato si« \\ Sažetak}

Kršćani ispovijedaju svoju vjeru u Boga Stvoritelja neba i zemlje. Pitanje je imaju li kršćani drukčiji odnos prema stvaranju od onih koji ne gledaju na stvaranje u svjetlu vjere u Boga Stvoritelja. Većina ljudi nije svjesna činjenice da im izostaje punoća kršćanske duhovnosti ako njezin plod ne uključuje veću ekološku osviještenost koja se očituje u konkretnoj brizi za naš zajednički dom. Katolička je crkva dugo odgađala objavljivanje službenih dokumenata koji potiču vođenje brige o okolišu. Ovo oklijevanje nadvladao je papa Franjo u svojoj enciklici »Laudato sì«, u kojoj naglašava probleme ekološke nesigurnosti i indiferentnost mnogih kršćana u odnosu prema okolišu. Papa je uputio ovu encikliku čitavom čovječanstvu zato što je želio pozvati sve ljude da se ujedine u zajedničkom traženju i ostvarenju konkretne brige za naš zajednički dom. U ovom radu autor najprije želi predočiti Papinu kritiku, ali i ohrabrenje u rješavanju ekološke krize. Autor zatim govori o putu ekološke duhovnosti na koju je pozvano cijelo čovječanstvo, a osobito katolici. Na kraju autor donosi dva duhovna sredstva koja nam nudi ignacijevska duhovnosti (kontemplacija, egzamen), a koja će nam omogućiti nov odnos prema stvaranju koji ohrabruje ekološka duhovnost. Ključne riječi: ekološka duhovnost, papa Franjo, ekologija, »Laudato sì, trojedini Bog, stvaranje, ignacijevska duhovnost, kontemplacija, egzamen.

(na hrv. prev. Berislav Čović)

\footnotetext{
* Doc. dr. sc. Ivan Platovnjak, Sveučilište u Ljubljani, Teološki fakultet, Poljanska cesta 4, SI1000 Ljubljana, Slovenija; E-mail: ivan.platovnjak@teof.uni-lj.si.
} 